\title{
Insects associated with the composting process of solid urban waste separated at the source
}

\author{
Gladis Estela Morales ${ }^{1} \&$ Marta Wolff ${ }^{2}$
}

\begin{abstract}
'Grupo GEMA- Universidad de Medellín, Carrera 87 N³0-65 Medellín, Colombia. gmorales@udem.edu.co
${ }^{2}$ Grupo de Entomología, Universidad de Antioquia, Calle 67 Número 53 - 108, Apartado Aereo 1226, Medellín, Colombia. nataliaurma@gmail.com; mwolff@ matematicas.udea.edu.co
\end{abstract}

\begin{abstract}
Insects associated with the composting process of solid urban waste separated at the source. Sarcosaprophagous macroinvertebrates (earthworms, termites and a number of Diptera larvae) enhance changes in the physical and chemical properties of organic matter during degradation and stabilization processes in composting, causing a decrease in the molecular weights of compounds. This activity makes these organisms excellent recyclers of organic matter. This article evaluates the succession of insects associated with the decomposition of solid urban waste separated at the source. The study was carried out in the city of Medellin, Colombia. A total of 11,732 individuals were determined, belonging to the classes Insecta and Arachnida. Species of three orders of Insecta were identified, Diptera, Coleoptera and Hymenoptera. Diptera corresponding to $98.5 \%$ of the total, was the most abundant and diverse group, with 16 families (Calliphoridae, Drosophilidae, Psychodidae, Fanniidae, Muscidae, Milichiidae, Ulidiidae, Scatopsidae, Sepsidae, Sphaeroceridae, Heleomyzidae, Stratiomyidae, Syrphidae, Phoridae, Tephritidae and Curtonotidae) followed by Coleoptera with five families (Carabidae, Staphylinidae, Ptiliidae, Hydrophilidae and Phalacaridae). Three stages were observed during the composting process, allowing species associated with each stage to be identified. Other species were also present throughout the whole process. In terms of number of species, Diptera was the most important group observed, particularly Ornidia obesa, considered a highly invasive species, and Hermetia illuscens, both reported as beneficial for decomposition of organic matter.
\end{abstract}

KEYWORDS. Compost; Diptera; diversity; urban entomology.

RESUMEN. Insectos asociados al proceso de compostaje de residuos sólidos urbanos separados en la fuente. Los macroinvertebrados saprófagos (lombrices de tierra, termitas y numerosas larvas de de dípteros) contribuyen con la generación de cambios en las propiedades físicas y químicas de la materia orgánica durante los procesos de degradación y estabilización que se llevan a cabo durante el compostaje, lo cual causa una disminución de los pesos moleculares de los compuestos. Esta actividad hace estos organismos excelentes recicladores de la materia orgánica. Este estudio estuvo orientado a evaluar la sucesión de insectos asociados a la descomposición de residuos sólidos urbanos separados en la fuente, el cual fue realizado en una compostera ubicada en el Municipio de Medellín, Colombia. Se determinaron un total de 11732 individuos, pertenecientes a la Clase Insecta y Arachnida. Se identificaron especies de 3 órdenes de insecta: Diptera, Coleoptera e Hymenoptera. Diptera correspondió al $98.5 \%$ del total, fue el grupo mas abundante y diverso con 16 familias (Calliphoridae, Drosophilidae, Psychodidae, Fanniidae, Muscidae, Milichiidae, Ulidiidae, Scatopsidae, Sepsidae, Sphaeroceridae, Heleomyzidae, Stratiomyidae, Syrphidae, Phoridae, Tephritidae, Curtonotidae), seguido por los coleópteros con 5 familias (Carabidae, Staphylinidae, Ptiliidae, Hydrophilidae Phalacaridae). Se observaron tres fases durante el proceso de compostaje, en las cuales se pudo diferenciar las especies propias de cada y otras especies estuvieron durante todo el proceso. En términos de numero de especímenes, Diptera fue el grupo mas importante, particularmente el Syrphidae Ornidia obesa, como una especie altamente positivamente invasiva y el Stratiomyidae Hermetia illuscens, ambas reportadas como benéficas en la descomposición de la materia orgánica.

PALABRAS-CLAVE. Compostaje; Diptera; diversidad; entomología urbana.

Increasing human population, expansion of large cities and modernization processes have generated high volumes of all kinds of waste. Added to the lack of appropriate alternatives for its handling and disposal, this has caused significant pollution problems. The search for innovative alternatives for cleaner production standards with wastes being reincorporated into production systems are urgent (Pascual et al. 1997; Bhattacharyya et al. 2001; Smith \& Hughes 2004). Therefore, different methods have been proposed for waste treatment, with composting being one of the preferred ones (Lee et al. 2004; Sharholy et al. 2008). This alternative, as well as providing a solution to the problem, could lead to improved agricultural production, responding to a growth in agricultural demands.
Composting is defined as the biological oxidative decomposition of organic matter (Stoffella \& Kahn 2001) based on the catalytic activity of organisms present in the environment, responsible for the decomposition of organic matter. Under optimum conditions, and according to thermal indicators, three stages have been identified: 1) mesophilic, or moderate temperature phase; 2) thermophilic, or high temperature phase and 3) cooling or maturing phase (Kostov et al. 1996; Trautmann \& Olynciw 2000). The duration of these phases depends on the kind of organic matter being composted as well as its efficiency, which is determined by factors such as aeration and humidity (McKinley \& Vestal 1985; Strom 1985 a, b; Butler et al. 2001).

From a biological point of view, decomposing organic 
matter is the natural habitat of microorganisms such as yeast, fungi, bacteria and macroinvertebrates, of which most are insects (Jacobs 1998; Tuomela et al. 2000). Numerous species participate actively in the recycling process, feeding on animal and vegetal origin wastes (Haimi 2000). Compounds generated at the different decomposition stages attract an important diversity of arthropods whose life cycles are completed within the compost, while simultaneously contributing to, and speeding up, its decomposition. These arthropods also promote the presence and development of beneficial species, such as Hermetia illucens (Diptera, Stratiomyidae), which is involved in controlling the development of domestic flies in this kind of substrate (Calvert et al. 1970; Booram et al. 1977; Chio \& Chen 1982; Sheppard 1983; Newton et al. 1992, 1995).

This study aims to further knowledge of insects' role during the composting process of solid urban waste separated at source, and to provide information that will allow their utility to be determined as maturity indicators of materials generated by composting processes.

\section{MATERIAL AND METHODS}

The study took place in Belén Altavista, a rural district of Medellín, in the department of Antioquia (Colombia). The study site was located at an elevation of $1600 \mathrm{~m}$ with an annual average temperature of $22^{\circ} \mathrm{C}$, within the premontane moist forest life zone (Holdridge 1967).

A total of $4000 \mathrm{~kg}$ of solid urban waste separated at source, was placed in two piles, each consisting of a system of six beds measuring $150 \times 150 \times 70 \mathrm{~cm}$. Composting piles were built on a slightly sloping, waterproof, cement surface, in order to avoid contamination from groundwater, humidity transference from the ground to the compost and to enable an appropriate handling of leachates. Homogenization and airing of composting material was achieved through periodical turning.

To select the sampling sites was followed the methodology TMECC 02.01 proposed in Field sampling of compost material (TMECC 2001), sampling different sites in the bed, from surface to a $30 \mathrm{~cm}$ depth, homogenizing and mixing all the subsamples.

To evaluate arthropod communities present at different stages, three samples were taken per day during the first week (7:00, 12:00 and 17:00 hours), then, twice a day during the second week (11:00 and 18:00 hours) and once a day (12:00 hours) until the seventh week. Each sample consisted of 1 $\mathrm{kg}$ of compost taken from nine different points from each bed in order to obtain a representative sample including both immature and adult specimens. Each sample was separated into two parts, one was deposited in plastic recipients covered with muslin until adults emerged and immature stadiums were extracted from the other using a Berlese funnel. Specimens were later identified using dichotomous keys by Borror et al. (1989), McAlpine et al. (1993), Peterson (1960) and Sterh (1987).

Two statistical packages were used to analyze data: PAS, used to calculate diversity, dominance and equitability indices over the study period, and SPSS to calculate correlations between insects.

Shannon \& Weaver diversity index implies that every species be represented in the sample and that these populations are heterogeneous. Maximum value is expressed by $\ln \mathrm{S}$, being $\mathrm{S}$ the number of taxons per sample, but range usually oscillates between 1,5 and 3,5. Dominance index provides an abundance measure for the most common species; the most frequently used is the Simpson index. As dominance index increases from 0 to 1 , diversity and equity decreases. It is an index highly influenced by dominant species in sample. Equity index describes the abundance distribution for species and oscillates between 0 as the minimum equity to lower diversity and 1 , maximum equity to higher diversity (Ramírez 2000).

To describe spatial patterns (random, uniform o grouped), one of the most typical ecological features of a species, the relationship between variance and media was analyzed with Taylor Power Law (Taylor 1984). Taylor coefficients $\mathrm{S}^{2}=\mathrm{a}$. $\mathrm{m}^{\mathrm{b}}$ were calculated using linear regression for the logarithm of variance $\left(\mathrm{S}^{2}\right)$ versus logarithm of sample mean $(\mathrm{m})$. Regression slope $\log \left(\mathrm{S}^{2}\right)=\log (\mathrm{a})+\mathrm{b}$. $\log (\mathrm{m})$ is considered an aggregation index, so $\mathrm{b}=1$ indicates a random pattern, $\mathrm{b}<$ 1 is a uniform pattern and $b>1$ indicates a grouped pattern.

\section{RESULTS}

A total of 11,732 individuals were collected throughout the study. Individuals within Insecta belonged to three orders: Diptera $(\mathrm{N}=11,561)$, corresponding to $98.5 \%$ of the total; Coleoptera $(\mathrm{N}=81)$ and Hymenoptera $(\mathrm{N}=20)$. One species of Arachnida was also collected. Diptera represented the most abundant and diverse group with 16 families (Calliphoridae, Drosophilidae, Psychodidae, Fannidae, Muscidae, Milichiidae, Ulidiidae, Scatopsidae, Sepsidae, Sphaeroceridae, Heleomyzidae, Stratiomyidae, Syrphidae, Phoridae, Tephritidae and Curtonotidae) followed by Coleoptera with five families (Carabidae, Staphylinidae, Ptilidae, Hydrophilidae and Phalacaridae) (Table I).

\section{Diptera families recorded}

Syrphidae. The highest number of individuals was collected from this family throughout the entire study period $(\mathrm{N}=5700)$, but especially during weeks 4,6 and 7 when a relative abundance of $100 \%$ was registered (Tables I and IV). This family was represented only by Ornidia obesa (Fabricius, 1775), present from the first day, and representing $89.09 \%$ of the total number of individuals collected on day 20 (Table II).

Milichiidae._This was the second most abundant species $(\mathrm{N}=1565)$, with percentages of $100 \%$ during weeks 4,5 and 6 (tables 1 and 4). It was represented only by the genus Desmometopa sp, which was found during the entire study period. Highest abundance was observed on days 0 and 15 , with presence during the entire period (Fig. 1, Table II).

Muscidae. This family was represented by Stomoxys 


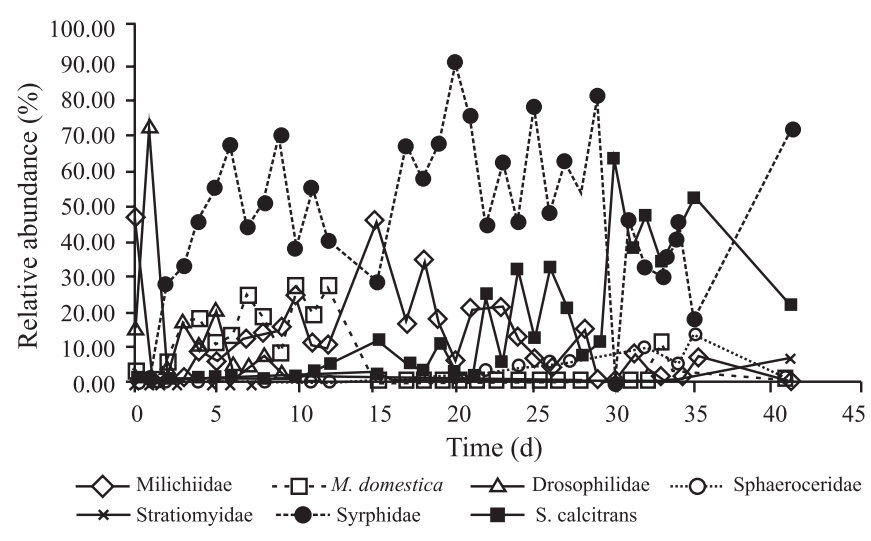

Fig. 1. Relative abundance for families having presence during the entire composting process.

calcitrans (Linnaeus, 1758) (12.02\%), Musca domestica (Linnaeus, 1758$)(10.88 \%)$ and Ophyra aenescens (Wiedemann, 1830) (0.14\%). S. calcitrans $(\mathrm{N}=1410)$ showed an increase from day 20 (Figure 1, Table II), with highest relative abundance during weeks 4, 5 and 6 (Tables I and IV). Highest abundance of M. domestica $(\mathrm{N}=1276)$ was recorded during the second week of the composting process $(27.27 \%)$, but the species was not recorded in the last week (Tables I, II and IV). O. aenescens, was poorly represented with only 17 individuals; this species was just observed during week 3 . (Tables I, II and IV).

Drosophilidae. This family was represented by the genus Drosophila $(\mathrm{N}=470)$, it was found throughout the study period being particularly abundant during weeks 1,2 and 6 (Tables 1 and 4 ); the highest percentage $(71.43 \%)$ was observed on the first day (Figure 1, Table II).

Fanniidae. This family was represented solely by Fannia canicularis (Linnaeus, 1761) $(\mathrm{N}=348)$, it was present during the first 5 weeks of the study, with a subtle increase in relative abundance during the first and fifth week, and with a total absence during weeks 6 and 7 (Tables I and IV). The highest percentage was recorded on day 12 , with $9.82 \%$ (Table II).

Sphaeroceridae. While poorly represented $(\mathrm{N}=227)$, this family was recorded throughout the whole composting process, showing highest abundance during weeks 5 and 6 (Tables I and IV), with the highest percentage of individuals on day 30 (Table II).

Stratiomyidae. The only species within this family, with a total representation of $1.93 \%$ (Table I), was Hermetia illucens (Linnaeus, 1758), observed throughout the whole study period, but particularly from weeks 3 to 7 (Table IV). The highest increase was recorded on day 28 (Table II).

Families with numbers of individuals between 40 and 100 were: Tephritidae, Scatopsidae, Ulidiidae and Phoridae, all of which were present during the first two weeks but totally absent during weeks 6 and 7 (Tables I, IV).

Less than 40 individuals of the following families were recorded: Sepsidae, Psychodidae and Heleomyzidae; the first two were present during weeks 1 and 2. Heleomyzidae was present during weeks 2 and 5 (Tables I, IV).
The orders Coleoptera and Hymenoptera were observed in low numbers, with Staphylinidae the most abundant within Coleoptera $(\mathrm{N}=41)$ and Formicidae in Hymenoptera $(\mathrm{N}=14)$; less than 5 individuals were recorded from other families.

Ecological indicators. In general, low values of the Shannon-Wiener diversity index were recorded, with a slight decreasing trend in time (Fig. 2). The highest value was recorded during week 1 , specifically on day $3\left(H^{\prime}=1.754\right)$, with an evident decrease in diversity in week $7\left(\mathrm{H}^{\prime}=0.80\right)$. With respect to diversity within families, this index was only calculated for Muscidae, with the following species $S$. calcitrans, $M$. domestica and $O$. aenescens given that only one species per family was recorded for all other families.

The highest dominance value was recorded on day 20 $(\mathrm{D}=0.8973)$, coinciding with the lowest diversity value $\left(\mathrm{H}^{\prime}\right.$ $=0.45495)$, attributed to a high relative $O$. obesa presence (Table II).

Although a large total number of organisms was recorded, they were distributed equally in each sample, shown by the equity index fluctuating between 0.3272 (day 20) and 0.7618 (day 3). From day 21 until the end of the process, index values remained constant, corroborating the stability of the system (Figure 2).

There was always a relationship, meaning this, always that the average increased, the variance increased as well, for all of the species. This can be proved by applying a simple regression analysis of which the positive slope demonstrates such relation.

Independently of the simple regression analysis model applied it was observed that the coefficient for every species was positive: Drosophilidae $(\mathrm{r}=0.8427)$, Fanniidae $(0.9958)$, Milichiidae (0.9869), M. domestica $(\mathrm{r}=0.9857)$, S. calcitrans $(\mathrm{r}=0.9887)$, Scatopsidae $(\mathrm{r}=0.9969)$, Sphaeroceridae $(\mathrm{r}=$ $0.9484)$, Stratiomyidae $(r=0.9617)$, Syrphidae $(r=0.4767)$, Ulidiidae $(r=0.9598)$.

Correlation matrix. The highest correlations were found between Psychodidae and Sepsidae (0.717; $P<<0.005)$; Sphaeroceridae and S. calcitrans (Muscidae) $(0.759 ; P<<$

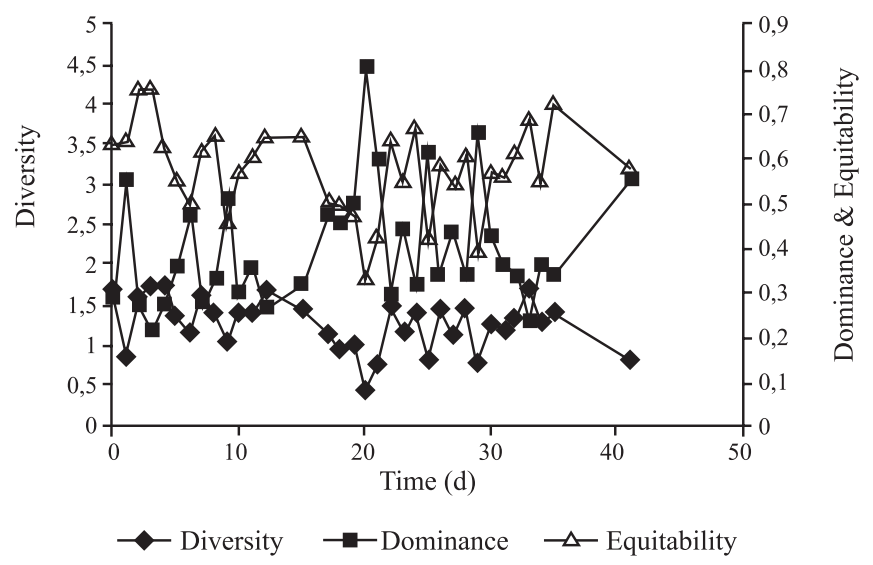

Fig. 2. Ecological indices during composting processes. 
Table I. Insects found in solid urban waste compost. N, individuals; RA, relative abundance; L, larvae.

\begin{tabular}{|c|c|c|c|c|c|c|}
\hline Order & Family & Subfamily & Genus & Species & $\mathrm{N}$ & RA \\
\hline \multirow[t]{18}{*}{ Diptera } & Syrphidae & Eristalinae & Ornidia & O. obesa & 5,700 & 48.58 \\
\hline & Milichiidae & Madizinae & Desmometopa & Desmometopa sp. & 1,565 & 13.34 \\
\hline & Muscidae & Stomoxyinae & Stomoxys & S. calcitrans & 1,410 & 12.02 \\
\hline & Muscidae & Muscinae & Musca & M. domestica & 1,276 & 10.88 \\
\hline & Drosophilidae & & Drosophila & Drosophila sp. & 470 & 4.01 \\
\hline & Fanniidae & & Fannia & F. canicularis & 348 & 2.97 \\
\hline & Sphaeroceridae & Limosininae & Coproica & Coproica sp. & 227 & 1.93 \\
\hline & Stratiomyidae & Hermetiinae & Hermetia & H. illucens & 226 & 1.93 \\
\hline & Tephritidae & & & & 95 & 0.81 \\
\hline & Scatopsidae & Scatopsinae & Coboldia & C. fuscipes & 68 & 0.58 \\
\hline & Ulidiidae & Ulidiinae & Physiphora & Physiphora sp. & 67 & 0.57 \\
\hline & Phoridae & Metopininae & Chonocephalus & Chonocephalus sp. & 41 & 0.35 \\
\hline & Sepsidae & Sepsinae & Themira & Themira sp. & 24 & 0.20 \\
\hline & Muscidae & Azeliinae & Ophyra & O. aenescens & 17 & 0.14 \\
\hline & Heleomyzidae & & & & 15 & 0.13 \\
\hline & Psychodidae (L) & & & & 6 & 0.05 \\
\hline & Calliphoridae (L1) & & & & 3 & 0.03 \\
\hline & Curtonotidae & & Curtonotum & Curtonotum sp. & 3 & 0.03 \\
\hline \multirow[t]{5}{*}{ Coleoptera } & Staphylinidae & & & & 41 & 0.35 \\
\hline & Hydrophilidae & & & & 5 & 0.04 \\
\hline & Ptiliidae & & & & 2 & 0.02 \\
\hline & Carabidae & & & & 1 & 0.01 \\
\hline & Phalacridae & & Stilbus & S. apilaclis & 1 & 0.01 \\
\hline \multirow[t]{4}{*}{ Hymenoptera } & Formicidae & Formicinae & Paratrechina & Paratrechina sp. & 14 & 0.12 \\
\hline & & Dolichoderinae & Dorymyrmex & Dorymyrmex sp. & 4 & 0.03 \\
\hline & & Ecitoninae & Neivamirmex & Neivamirmex sp. & 1 & 0.01 \\
\hline & Scelionidae & & & & 1 & 0.01 \\
\hline
\end{tabular}

0.005); and Phoridae and Calliphoridae (0.743; $P<<0.005)$.

The lowest correlations with a significant $P$ value were found between Scatopsidae - Drosophilidae $(0.682 ; P=$ 0.000); Phoridae - Drosophilidae (0.651; $P=0.000), M$. domestica (Muscidae) - Fanniidae $(0.90 ; P=0.000)$; Phoridae - Syrphidae (0.561; $P=0.001)$, Milichiidae - Calliphoridae (0.498; $P=0.03)$; Heleomyzidae - Psychodidae $(0.449 ; P$ $=0.008)$; Sphaeroceridae - Syrphidae $(-0.496 ; P=0.003)$; Drosophilidae - Syrphidae $(-0.474 ; P=0.005)$ and $S$. calcitrans (Muscidae) - Syrphidae (-0.344; $P=0.046)$. A highly significant correlation was found between the latter two after week 3.

Spatial distribution. Spatial distribution showed grouped pattern of insects, especially for those which weren't present during all the composting stages. In the case of $O$. obesa species, the follow equation was obtained: $\log$ variance $=$ $2.55715+0.568466 * \log$ average, with a slope minor to 1 , expressing an uniform pattern. The other species showed a slope mayor to 1 , showing a grouped pattern, in the following order: Ulidiidae (b: 3.55514, r: 0.961), Fanniidae (b: 2.5942, r: 0.9618), Scatopsidae (2.25439, r: 0.967), Milichiidae (b:2.0577, r: 0.9688), Drosophilidae (b: 1.93867, r: 0.9321), Stratiomyidae (b: 1.93593, r: 0.961), Sphaeroceridae (b: 1.82796, r: 0.948), Muscidae (M. domestica) (b: 1.67191, r: 0.9657), Muscidae (S. calcitrans) (b: 1.63327, r: 0.98). Some authors attribute cluster pattern, especially in small size species, is due to eclosion of larvae from egg masses, which coincides with most of the studied species. Random patter in observed in big size larvae, as $O$. obesa.

Compost system phases. According to Zbytniewski \& Buszewski (2005), three stages may be differentiated during the composting process: 1) decomposition of easily biodegradable substances, 2) formation of humus-like substances, and 3) stabilization of organic matter. These stages were also differentiated during the present study and were associated with characteristic insects at each stage of the decomposition process:

Stage 1: Weeks $1-3$. The presence of Phoridae and $O$. aenescens stand out as possible indicators of this stage. During

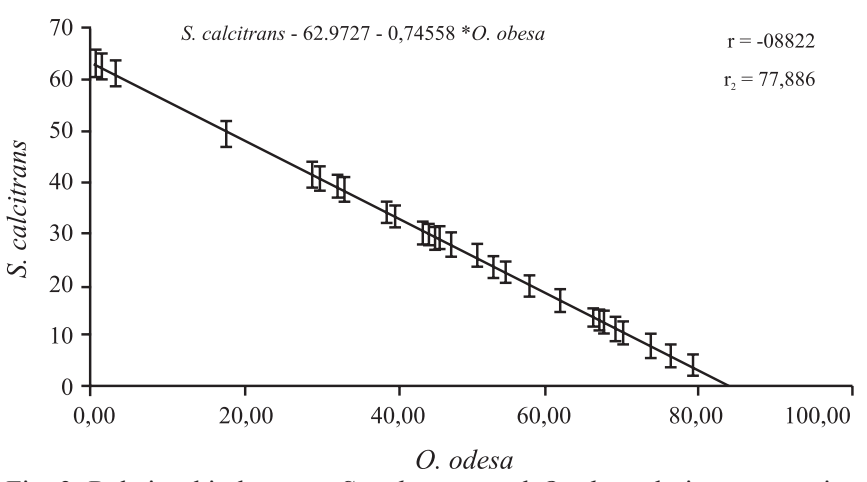

Fig. 3. Relationship between S. calcitrans and $O$. obesa during composting process. 
Table II. Relative percentage of insect succession by family for Diptera.

\begin{tabular}{|c|c|c|c|c|c|c|c|c|c|c|c|c|c|c|c|c|c|c|}
\hline \multirow[b]{2}{*}{ Day } & \multirow[b]{2}{*}{ 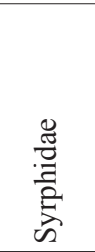 } & \multirow[b]{2}{*}{ 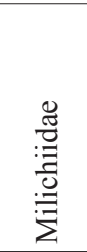 } & \multicolumn{3}{|c|}{ Muscidae } & \multirow[b]{2}{*}{ 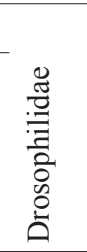 } & \multirow[b]{2}{*}{ 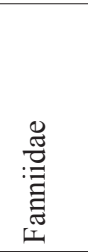 } & \multirow[b]{2}{*}{ 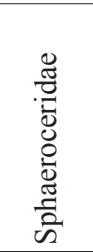 } & \multirow[b]{2}{*}{ 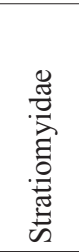 } & \multirow[b]{2}{*}{ 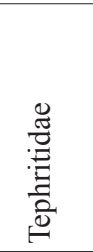 } & \multirow[b]{2}{*}{ 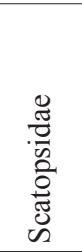 } & \multirow[b]{2}{*}{ 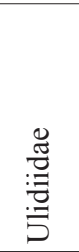 } & \multirow[b]{2}{*}{$\frac{\tilde{\pi}}{0}$} & \multirow[b]{2}{*}{ 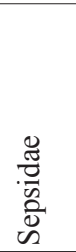 } & \multirow[b]{2}{*}{ 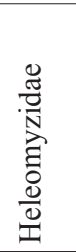 } & \multirow[b]{2}{*}{ 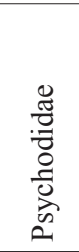 } & \multirow[b]{2}{*}{ 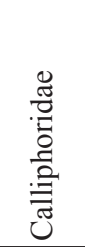 } & \multirow[b]{2}{*}{ 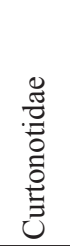 } \\
\hline & & & 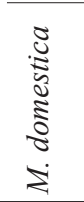 & 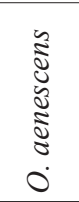 & 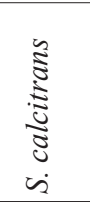 & & & & & & & & & & & & & \\
\hline 0 & 0.72 & 47.10 & 3.62 & 0.00 & 2.90 & 15.22 & 0.72 & 0.00 & 0.72 & 3.62 & 0.72 & 1.45 & 18.84 & 0.00 & 0.00 & 0.00 & 1.45 & 0.00 \\
\hline 1 & 0.00 & 0.00 & 0.00 & 0.00 & 0.00 & 71.43 & 0.00 & 0.00 & 0.00 & 0.00 & 4.76 & 0.00 & 14.29 & 0.00 & 0.00 & 0.00 & 0.00 & 0.00 \\
\hline 2 & 29.41 & 0.00 & 5.88 & 0.00 & 0.00 & 2.94 & 8.82 & 2.94 & 0.00 & 0.00 & 0.00 & 2.94 & 5.88 & 0.00 & 0.00 & 0.00 & 0.00 & 0.00 \\
\hline 3 & 33.25 & 0.53 & 16.62 & 0.00 & 0.00 & 18.21 & 5.80 & 2.37 & 2.11 & 18.47 & 2.37 & 0.00 & 0.00 & 0.00 & 0.00 & 0.00 & 0.00 & 0.00 \\
\hline 4 & 45.97 & 9.06 & 18.12 & 0.00 & 0.67 & 10.74 & 5.03 & 0.34 & 0.34 & 1.34 & 1.68 & 1.01 & 0.34 & 4.03 & 0.00 & 0.67 & 0.34 & 0.00 \\
\hline 5 & 54.37 & 6.41 & 11.37 & 0.00 & 1.17 & 20.85 & 3.50 & 0.00 & 0.29 & 0.29 & 0.29 & 0.00 & 0.87 & 0.00 & 0.00 & 0.00 & 0.00 & 0.15 \\
\hline 6 & 66.58 & 9.97 & 13.21 & 0.00 & 2.02 & 4.58 & 1.48 & 0.94 & 0.40 & 0.00 & 0.00 & 0.00 & 0.00 & 0.27 & 0.00 & 0.00 & 0.00 & 0.00 \\
\hline 7 & 43.73 & 12.71 & 25.08 & 0.00 & 1.32 & 3.47 & 2.15 & 6.60 & 0.00 & 0.00 & 0.17 & 1.65 & 0.17 & 0.17 & 1.98 & 0.50 & 0.00 & 0.00 \\
\hline 8 & 50.70 & 13.95 & 19.07 & 0.00 & 0.47 & 7.44 & 6.05 & 0.00 & 0.47 & 0.00 & 1.40 & 0.47 & 0.00 & 0.00 & 0.00 & 0.00 & 0.00 & 0.00 \\
\hline 9 & & & & 0.00 & & & & & & & & & & & & 00 & & .00 \\
\hline 10 & 38.57 & 25.65 & 27.19 & 0.00 & 1.72 & 0.54 & 3.52 & 0.00 & 0.63 & 0.09 & 0.00 & 7 & 0.00 & 0.00 & 0.00 & 0.00 & 0.00 & 0.09 \\
\hline 11 & 54.52 & 10.54 & 19.25 & 0.00 & 2.04 & 0.86 & 8.49 & 0.00 & 1.94 & 0.43 & 1.83 & 0.00 & 0.00 & 0.00 & 0.00 & 0.00 & 0.00 & 0.00 \\
\hline 12 & 40.00 & 9.82 & 27.27 & 0.00 & 4.91 & 0.36 & 9.82 & 0.00 & 2.00 & 0.18 & 3.27 & 0.73 & 0.00 & 1.09 & 0.00 & 0.00 & 0.00 & 0.00 \\
\hline 15 & 28.99 & 46.01 & 1.86 & 0.00 & 11.44 & 0.00 & 6.38 & 2.39 & 2.13 & 0.00 & 0.00 & 0.53 & 0.00 & 0.00 & 0.00 & 0.00 & 0.00 & 0.00 \\
\hline 17 & 66.57 & 16.57 & 0.28 & 4.78 & 4.78 & 0.00 & 1.97 & 0.00 & 4.21 & 0.00 & 0.28 & 0.28 & 0. & 0.00 & 0.00 & 0.00 & 0.00 & 0.00 \\
\hline 18 & 57.98 & 34.63 & 0.00 & 0.00 & 3.11 & 0.00 & 0.78 & 0.00 & 2.72 & 0.00 & 0.00 & 0.00 & 0.00 & 0.00 & 0.00 & 0.00 & 0.00 & 0.00 \\
\hline 19 & 67.30 & 17.78 & 0.00 & 0.00 & 11.43 & 0.00 & & 0.00 & 0.63 & 0.00 & 0.00 & 0.00 & & 0.00 & 0.00 & 0.00 & 0.00 & 0.00 \\
\hline 20 & & & & 0. & & & & & & & & & & & & & & .00 \\
\hline 21 & 74.21 & 20.75 & 0.00 & 0.00 & 0.63 & 0.00 & 1.26 & 0.00 & 2.52 & 0.00 & 0.63 & 0.00 & 0 & 0.00 & 0.00 & 0.00 & 0.00 & 0.00 \\
\hline 22 & 44.16 & 20.13 & 0.65 & 0.00 & 24.68 & 0.00 & 2.60 & 2.60 & 0.65 & 0.00 & 1.95 & 1.30 & 0.00 & 0.00 & 0.00 & 0.00 & 0.00 & 0.00 \\
\hline 23 & 62.10 & 21.77 & 0.00 & 0.00 & 4.84 & 0.00 & 1.61 & 1.08 & 6.72 & 0.00 & 0.00 & 1.08 & 0.00 & 0.00 & 0.00 & 0.00 & 0.00 & 0.00 \\
\hline 24 & 44.89 & 12.44 & 0.00 & 0.00 & 31.56 & 0.00 & 0.89 & 4.00 & 1.33 & 0.00 & 0.00 & 2.67 & & 0.00 & 0.00 & 0.00 & 0.00 & 0.00 \\
\hline 25 & 76.89 & 6.13 & 0.00 & 0.00 & 12.26 & 0.00 & 0.94 & 0.47 & 2.83 & 0.00 & 0.47 & 0.00 & 0.00 & 0.00 & 0.00 & 0.00 & 0.00 & 0.00 \\
\hline 26 & 47.52 & 3.72 & 0.41 & 0.00 & 32.23 & 0.00 & 3.72 & 5.37 & 0.83 & 0.00 & 0.00 & 0.41 & 0.00 & 0.83 & 0.00 & 0.00 & 0.00 & 0.00 \\
\hline 27 & 61.86 & 5.77 & 0.00 & 0.00 & 21.47 & 0.32 & 0.00 & 0.00 & 7.69 & 0.00 & 0.32 & 2.24 & 0.00 & 0.00 & 0.00 & 0.00 & 0.00 & 0.00 \\
\hline 28 & 53.13 & 15.54 & 10.28 & 0.00 & & 0.25 & 0.50 & 0.00 & 9.27 & 2.01 & 0.00 & 0.50 & 0.00 & 0.00 & 0.00 & 0.00 & 0.00 & 0.25 \\
\hline 29 & 79.80 & 3.45 & 0.00 & 0.00 & 10.84 & 0.00 & 0.99 & 0.49 & 3.94 & 0.00 & 0.00 & 0.00 & 0.00 & 0.00 & 0.00 & 0.00 & 0.00 & 0.00 \\
\hline 30 & 2.80 & & 0.00 & 0.00 & 62.24 & 0.00 & 2.10 & 17.48 & 2.10 & 0.00 & 0.00 & 0.70 & 0.00 & 0.00 & 0.70 & 0.00 & 0.00 & 0.00 \\
\hline 31 & 45.51 & 8.08 & 0.00 & 0.00 & & 5.99 & & & 0.00 & 0.00 & & & & & 0.00 & 0.00 & 0.00 & 0.00 \\
\hline 32 & 32.37 & 4.91 & 0.00 & 0.00 & 46.82 & 4.05 & 0.58 & 9.25 & 0.00 & 0.00 & 0.00 & 0.29 & 0.00 & 0.00 & 0.00 & 0.29 & 0.00 & 0.00 \\
\hline 33 & 29.93 & 1.79 & 11.29 & 0.00 & 33.87 & 5.38 & 0.36 & 1.43 & 1.97 & 0.00 & 0.00 & 0.36 & 0.00 & 0.00 & 0.00 & 0.00 & 0.00 & 0.00 \\
\hline 34 & 44.73 & 2.11 & 0.00 & 0.00 & 39.66 & 2.95 & 0.42 & 4.64 & 2.95 & 0.00 & 0.84 & 0.00 & 0.00 & 0.00 & 0.84 & 0.00 & 0.00 & 0.00 \\
\hline 35 & 17.55 & 6.27 & 2.51 & 0.00 & 52.66 & 6.58 & 0.00 & 13.48 & 0.94 & 0.00 & 0.00 & 0.00 & 0.00 & 0.00 & 0.00 & 0.00 & 0.00 & 0.00 \\
\hline 41 & 70.73 & 0.00 & 0.00 & 0.00 & 21.95 & 0.00 & 0.00 & 0.00 & 6.10 & 0.00 & 0.00 & 1.22 & 0.00 & 0.00 & 0.00 & 0.00 & 0.00 & 0.00 \\
\hline
\end{tabular}

this stage, all recorded families were observed, indicating a higher diversity, represented mainly by Syrphidae, Milichiidae, S. calcitrans (Muscidae), Drosophilidae, M. domestica (Muscidae), Fanniidae, Stratiomyidae and Scatopsidae (Fig. 4).

Stage 2: Weeks 4-5. Families showing important increases were Milichiidae, Fanniidae, S. calcitrans (Muscidae), Stratiomyidae, Sphaeroceridae, Uliiddidae, Psychodidae and Heleomyzidae. The latter two, as well as Curtonotidae, are important yet not exclusive at this stage.

Stage 3: Weeks $6-7$. A low diversity is characteristic of this stage, with absence of most of the families: Fanniidae, Scatopsidae, Tephritidae, Uliididae, Sepsidae, Phoridae, Calliphoridae, Curtonotidae, Psychodidae, O. aenescens (Muscidae) and Heleomyzidae (Figure 4). Remaining families are stable throughout this stage, without important changes.
Although temperature has been associated with different stages of the composting process, this study found that while environmental temperature remained constant, compost temperature decreased, without notable differentiation between stages (Fig. 5).

\section{DISCUSSION}

Eighteen species of Diptera were recorded during the decomposition process of solid urban waste separated at source in which both larvae and adults were collected, demonstrating that this kind of substrate is apt for feeding, egg laying and the development of individuals.

Three different stages were recorded during the decomposition process: 1) easily biodegradable substrates, 2) formation of humus-like substances and 3) stabilization of organic matter. 
Of the families collected during this study, Calliphoridae, Muscidae, Fanniidae and Syrphidae have already been associated with composting processes (Laos et al. 2004). Presence and permanence is considered to depend on the availability of food sources and in some cases, on favorable environmental conditions (Sharanowski et al. 2008; Montoya et al. 2009).

Among the species recorded, Desmometopa sp. (Milichiidae) showed the highest relative abundance, reaching a maximum on day $0(47.10 \%)$, implying that it is a pioneer in this kind of waste. Larvae of this family are saprophagous or coprophagous (Sabrosky 1987) and this behavior performs a recycling function in this substrate. Another pioneer species with similar behavior was Drosophila sp., associated with decomposing fruit (Wheeler 1987).

Ornidia obesa is reported to be of great importance to the composting process due to its presence throughout every stage. This species has been associated with decomposition of organic matter, mainly coffee pulp, being considered beneficial in recycling of organic matter (Lardé 1989; 1990). Its correlation with species such as Chonochepalus sp., Coproica sp., Drosophila sp. and S. calcitrans suggests than $O$. obesa participates in the decrease of the former species.

Occasional presence and low abundance of Calliphoridae, Heleomyzidae and Psychodidae, as well as Curtonotum sp. (Curtonotidae), O. aenescens (Muscidae) and Themira sp. (Sepsidae), indicate that they have little effect on the composting process. This contrasts with the occasional presence but high abundance of Tephritidae, Chonocephalus sp. (Phoridae) and Drosophila sp. (Drosophilidae) at the beginning of the process, coinciding with stages of increased decomposition of organic matter (Sharanowski et al. 2008).

Sepsidae is present only during the first two weeks,

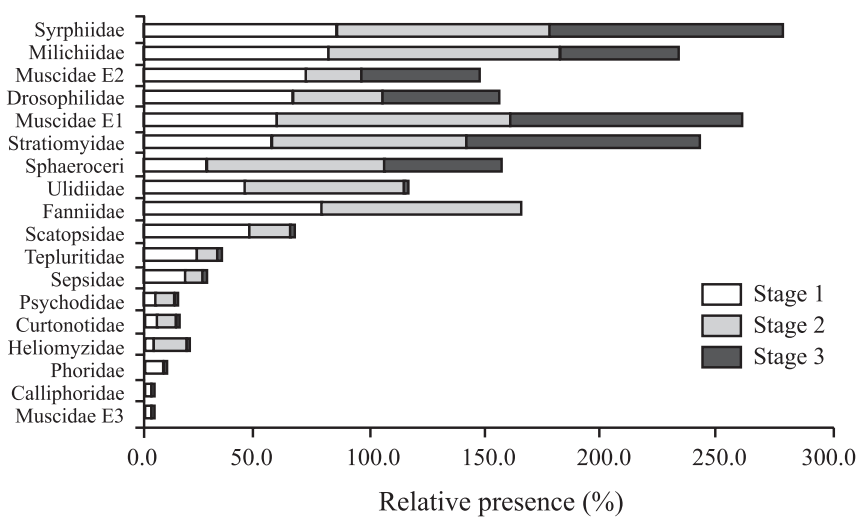

Fig. 4. Relative presence of Diptera larvae during composting process stages. (E1: S. calcitrans, E2: M. domestica, E3: O. aenescens).

reappearing again at week 4 , with a relatively low presence (Table IV). According to other studies, this family is more closely related to decomposition of organic matter of animal origin. Thus it is of higher interest to studies of forensic entomology rather than decomposition of solid urban waste (Sharanowski et al. 2008; Wang et al. 2008; Martinez et al. 2007).

The family Fanniidae was found almost throughout the whole composting process, with a maximum relative abundance of $9.82 \%$ at day 12. Larva can generate gastric myiasis, urinary myiasis and ear myiasis among others (Yang et al. 2005; Arsalane et al. 2001; Perez \& Mouffok 1999). Both this family and M. domestica (Muscidae) are important in animal health (Chakrabarti et al. 2007).

A high relative abundance of $S$. calcitrans during the whole composting process is especially noteworthy, due to

Table III. Diptera larvae succession matrix during composting process (presence - absence by sampling day). d, day.

\begin{tabular}{|c|c|c|c|c|c|c|c|c|c|c|c|c|c|c|c|c|c|c|c|c|c|c|c|c|c|c|c|c|c|c|c|c|c|c|}
\hline \multirow{2}{*}{ Taxa } & \multicolumn{34}{|c|}{ Time (d) } \\
\hline & 0 & 1 & 2 & 3 & 4 & 5 & 6 & 7 & 8 & 9 & 10 & 11 & 12 & 15 & 17 & 18 & 19 & 0 & 21 & 22 & 23 & 24 & 25 & 26 & 27 & 28 & 29 & 30 & 313 & 32 & 33 & 34 & 35 & 41 \\
\hline 1 & 1 & 0 & 0 & 0 & 0 & 0 & 0 & 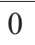 & 0 & 0 & 0 & 0 & 0 & 0 & 0 & 0 & 0 & 0 & 0 & 0 & 0 & 0 & 0 & 0 & 0 & 0 & 0 & 0 & 0 & 0 & 0 & 0 & 0 & 0 \\
\hline 2 & 0 & 0 & 0 & 0 & 0 & 1 & 0 & 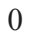 & 0 & 0 & 1 & 0 & 0 & 0 & 0 & 0 & 0 & & 0 & 0 & 0 & 0 & 0 & 0 & 0 & 1 & 0 & 0 & 0 & 0 & 0 & 0 & 0 & 0 \\
\hline 3 & 1 & 1 & 1 & 1 & 1 & 1 & 1 & 1 & 1 & 1 & 1 & 1 & 1 & 0 & 0 & 0 & 0 & 1 & 0 & 0 & 0 & 0 & 0 & 0 & 1 & 0 & 0 & 0 & 1 & 1 & 1 & 1 & 1 & 0 \\
\hline 4 & 0 & 0 & 1 & 1 & 1 & 1 & 1 & 1 & 1 & 0 & 1 & 1 & 1 & 1 & 1 & 1 & 1 & 0 & 1 & 1 & 1 & 1 & 1 & 1 & 0 & 1 & 1 & 1 & 0 & 1 & 1 & 1 & 0 & 0 \\
\hline 5 & 0 & 0 & 0 & 0 & 0 & 0 & 0 & 1 & 0 & 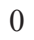 & 0 & 0 & 0 & 0 & 0 & 0 & 0 & 0 & 0 & 0 & 0 & 0 & 0 & 0 & 0 & 0 & 0 & 1 & 0 & 0 & 0 & 1 & 0 & 0 \\
\hline 6 & 1 & 0 & 0 & 1 & 1 & 1 & 1 & 1 & 1 & 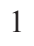 & 1 & 1 & . & 1 & 1 & 1 & 1 & 0 & 1 & 1 & 1 & 1 & 1 & 1 & 1 & 1 & 1 & 1 & 1 & 1 & 1 & 1 & 1 & 0 \\
\hline 7 & 1 & 0 & 1 & 1 & 1 & 1 & 1 & 1 & 1 & 0 & 1 & 1 & 1 & 1 & 1 & 0 & 0 & 0 & 0 & 1 & 0 & 0 & 0 & 0 & 0 & 1 & 0 & 0 & 0 & 0 & 1 & 0 & 1 & 0 \\
\hline 8 & 0 & 0 & 0 & 0 & 0 & 0 & 0 & 0 & 0 & 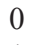 & 0 & 0 & 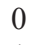 & 0 & 1 & 0 & 0 & 0 & 0 & 0 & 0 & 0 & 0 & 0 & 0 & 0 & 0 & 0 & 0 & 0 & 0 & 0 & 0 & 0 \\
\hline 9 & 0 & 0 & 0 & 0 & 1 & 1 & 1 & 1 & 1 & 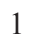 & 1 & 1 & 1 & 1 & 1 & 1 & 1 & 0 & 1 & 1 & 1 & 1 & 1 & 1 & 1 & 1 & 1 & 1 & 1 & 1 & 1 & 1 & 1 & 1 \\
\hline 10 & 0 & 0 & 0 & 0 & 1 & 1 & 0 & 1 & 0 & . & 0 & 0 & 0 & 0 & 0 & 0 & 0 & 0 & 0 & 0 & 0 & 0 & 0 & 0 & 0 & 0 & 0 & 0 & 0 & 0 & 0 & 0 & 0 & 0 \\
\hline 11 & 0 & 0 & 0 & 0 & 1 & 0 & 0 & 1 & c & 0 & 0 & 0 & c & 0 & 0 & 0 & 0 & C & 0 & 0 & 0 & 0 & 0 & 0 & 0 & 0 & 0 & 0 & 0 & 1 & 0 & 0 & 0 & 0 \\
\hline 12 & 1 & 1 & 0 & 1 & 1 & 1 & 0 & 1 & 1 & 1 & 0 & 1 & 1 & 0 & 1 & 0 & 0 & 0 & 1 & 0 & 0 & 0 & 0 & 0 & 1 & 0 & 0 & 0 & 0 & 0 & 0 & 1 & 0 & 0 \\
\hline 1 & 0 & 0 & 0 & 0 & 1 & 0 & 1 & 1 & 0 & 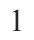 & 0 & 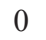 & 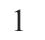 & 0 & 0 & 0 & 0 & 0 & 0 & 0 & 0 & 0 & 0 & 1 & 0 & 0 & 0 & 0 & 0 & 0 & 0 & 0 & 0 & 0 \\
\hline 14 & 0 & 0 & 1 & 1 & 1 & 0 & 1 & 1 & 0 & 1 & 0 & 0 & . & 1 & 0 & 0 & 0 & 0 & 0 & 0 & 1 & 1 & 1 & 1 & 0 & 0 & 1 & 1 & 1 & 1 & 1 & 1 & 1 & 0 \\
\hline 15 & 1 & 0 & 0 & 1 & 0 & 1 & 1 & 0 & 1 & 1 & 1 & 1 & 1 & 1 & 1 & 1 & 1 & 0 & 1 & 1 & 1 & 1 & 1 & 1 & 1 & 1 & 1 & 1 & 0 & 0 & 1 & 1 & 1 & 1 \\
\hline 16 & 0 & 0 & 1 & 1 & 1 & 1 & 1 & 1 & 1 & 1 & 1 & 1 & 1 & 1 & 1 & 1 & 1 & 1 & 1 & 1 & 1 & 1 & 1 & 1 & 1 & 1 & 1 & 0 & 1 & 1 & 1 & 1 & 1 & 1 \\
\hline 17 & 1 & 0 & 0 & 1 & 1 & 1 & 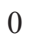 & . & 0 & 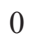 & 1 & 1 & 1 & 0 & 0 & 0 & 0 & 0 & 0 & 0 & 0 & 0 & 0 & 0 & 0 & 1 & 0 & 0 & 0 & 0 & 0 & 0 & 0 & 0 \\
\hline 18 & 1 & 0 & 1 & 0 & 1 & 0 & 0 & 1 & 1 & 1 & 1 & 0 & 1 & 2 & 1 & 0 & 0 & 0 & 0 & 1 & 1 & 1 & 0 & 1 & 1 & 1 & 0 & 1 & 1 & 1 & 0 & 0 & 0 & 1 \\
\hline
\end{tabular}

1. Calliphoridae, 2. Curtonotidae, 3. Drosophilidae, 4. Fanniidae, 5. Heleomyzidae, 6. Milichiidae, 7. M. domestica, 8. O. aenescens, 9. S. calcitrans, 10. Phoridae, 11. Psychodidae, 12. Scatopsidae, 13. Sepsidae, 14. Sphaeroceridae, 15. Stratiomyidae, 16. Syrphidae, 17. Tephritidae, 18. Ulidiidae. 
Table IV. Relative presence (\%) of Diptera during each week of the composting process.

\begin{tabular}{|c|c|c|c|c|c|c|c|c|}
\hline \multirow[t]{2}{*}{ Family } & \multirow{2}{*}{ Stadium } & \multicolumn{7}{|c|}{ Weeks } \\
\hline & & 1 & 2 & 3 & 4 & 5 & 6 & 7 \\
\hline \multirow{2}{*}{ Syrphidae } & Adult & 37.5 & 40 & 60 & 14.28 & 85.71 & 100 & 0 \\
\hline & Larva & 81.3 & 90 & 80 & 100 & 85.71 & 100 & 100 \\
\hline M. domestica & Adult & 25.0 & 30 & 20 & 14.28 & 14.28 & 0 & 0 \\
\hline (Muscidae) & Larva & 81.3 & 80 & 40 & 14.28 & 28.57 & 100 & 0 \\
\hline \multirow[t]{2}{*}{ Drosophilidae } & Adult & 12.5 & 10 & 40 & 0 & 14.28 & 100 & 0 \\
\hline & Larva & 81.3 & 70 & 20 & 14.28 & 57.14 & 100 & 0 \\
\hline \multirow[t]{2}{*}{ Milichiidae } & Adult & 25.0 & 20 & 40 & 28.57 & 85.71 & 100 & 0 \\
\hline & Larva & 75.0 & 90 & 80 & 100 & 100 & 100 & 0 \\
\hline \multirow[t]{2}{*}{ Fanniidae } & Adult & 12.5 & 0 & 0 & 28.57 & 14.28 & 0 & 0 \\
\hline & Larva & 75.0 & 80 & 80 & 85.71 & 85.71 & 0 & 0 \\
\hline \multirow[t]{2}{*}{ Scatopsidae } & Adult & 6.3 & 0 & 0 & 28.57 & 0 & 0 & 0 \\
\hline & Larva & 43.8 & 60 & 20 & 28.57 & 14.28 & 0 & 0 \\
\hline S. calcitrans & Adult & 18.75 & 20 & 40 & 14.28 & 71.42 & 100 & 100 \\
\hline (Muscidae) & Larva & 37.5 & 80 & 80 & 100 & 100 & 100 & 100 \\
\hline \multirow[t]{2}{*}{ Stratiomyidae } & Adult & 12.5 & 20 & 20 & 0 & 28.57 & 100 & 0 \\
\hline & Larva & 37.5 & 70 & 80 & 100 & 71.42 & 100 & 100 \\
\hline \multirow[t]{2}{*}{ Sphaeroceridae } & Adult & 0 & 0 & 0 & 14.28 & 0 & 100 & 0 \\
\hline & Larva & 31.25 & 30 & 20 & 57.14 & 85.71 & 100 & 0 \\
\hline Tephritidae & Larva & 31.25 & 30 & 0 & 0 & 14.28 & 0 & 0 \\
\hline \multirow[t]{2}{*}{ Ulidiidae } & Adult & 0 & 0 & 0 & 0 & 14.28 & 0 & 0 \\
\hline & Larva & 25 & 70 & 60 & 71.42 & 57.14 & 0 & 0 \\
\hline Sepsidae & Larva & 18.75 & 30 & 0 & 14.28 & 0 & 0 & 0 \\
\hline \multirow[t]{2}{*}{ Phoridae } & Adult & 25 & 0 & 20 & 0 & 0 & 0 & 0 \\
\hline & Larva & 12.5 & 10 & 0 & 0 & 0 & 0 & 0 \\
\hline \multirow[t]{2}{*}{ Calliphoridae } & Adult & 12.5 & 0 & 0 & 0 & 0 & 0 & 0 \\
\hline & Larva & 6.25 & 0 & 0 & 0 & 0 & 0 & 0 \\
\hline Curtonotidae & Larva & 6.25 & 10 & 0 & 0 & 14.28 & 0 & 0 \\
\hline Psychodidae & Larva & 6.25 & 10 & 0 & 0 & 14.28 & 0 & 0 \\
\hline $\begin{array}{l}\text { O. aenescens } \\
\text { (Muscidae) }\end{array}$ & Larva & 0 & 0 & 20 & 0 & 0 & 0 & 0 \\
\hline Heleomyzidae & Larva & 0 & 10 & 0 & 0 & 28.57 & 0 & 0 \\
\hline
\end{tabular}

both female and male being hematophagous (Mramba et al. 2007). Locally known as "stable fly", it is of public health interest, due to its irritating bite to animals and humans. In bovine livestock it causes weight loss, decrease in milk production and can lead to death in particular severe cases. This fly breeds in organic waste matter of both animal and vegetal origin, and is associated with the transmission of bovine annaplasmosis (Knapp et al. 1992; Miller 1992).

Despite their relatively low abundance, Physiphora sp. (Ulidiidae) and C. fuscipes (Scatopsidae) were found throughout almost the whole composting process.

A highly significant negative correlation was found between O. obesa and S. calcitrans after week 3 (Figure 3). These results are important given that the lineal regression model predicts that if $O$. obesa reaches abundances higher than $84 \%$ of the total arthropod population, S. calcitrans decreases. This can therefore be achieved by allowing the free propagation of $O$. obes $a$ without introducing control methods to eradicate $S$. calcitrans from the compost.

With respect to ecological indices (diversity, abundance and equity) very constant values were obtained, implying that despite large numbers of organisms, they are distributed uniformly throughout the study period, corroborating system stability. Additionally, highest diversity was found within
Muscidae, with three species (S. calcitrans, M. domestica and $O$. aenescens), given that in other families, only one species per family was recorded.

It was observed that as the composting process progresses, diversity of Diptera decreased. During the first week the presence of 17 taxa out of a total of 18 were recorded, but during the last week a significant presence of only three taxa was recorded: O. obesa (Syrphidae), S. calcitrans (Muscidae)

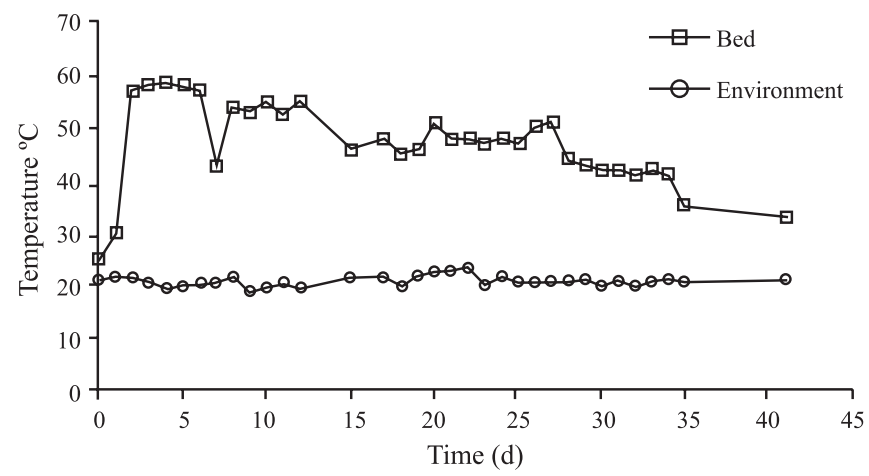

Fig. 5. Temperature against time during composting process. 
and $H$. illucens (Stratiomyidae). This corresponds to results reported by several authors, according to which a decrease in diversity is attributable to depredation by other Diptera species at the larval stage, also influencing their abundance (Labud et al. 2003).

Presence of $H$. illucens larvae, reported in other studies as consumers of decomposing organic matter and responsible for decreases of $M$. domestica, is clear evidence of the role of H. illucens in controlling M. domestica (Furman 1959 apud Williams 2005).

The composting process requires parameters that can be controlled as moisture, temperature, $\mathrm{pH}$, relation carbon/ nitrogen and metals; which is not opposite to the action of arthropods, who has a role of recycling, allowing a clean, efficient and low-cost alternative without insecticides as in traditionally intervention, getting at the end a high quality product with minimum of contaminates effects.

Acknowledgements. This study received financial support from CODI (Comite de Investigaciones Universidad de Antioquia) project number CPT0325 cc 9889 E00955.

\section{REFERENCES}

Arsalane, L.; A. Agoumi; A. Behjawi; A. Elhoum \& N. Bouazzaoui. 2001. Bilateral ear myiasis due to Fannia canicularis (Linne 1761). Médecine tropicale: revue du Corps de santé colonial 61: 548-549.

Bhattacharyya, P.; R. Pal; A. Chakraborty \& K. Chakrabarti. 2001. Microbial biomass and activity in a laterite soil amended with Municipal solid Waste Compost. Journal Agronomy \& Crop Science 187: 207-211.

Borror, D.; C. Triplehorn \& N. Johnson. 1989. An Introduction to the study of Insects. Sixth edition, Saunders College Publishing. 800 p.

Booram, C. V.; G. L. Newton; O. M. Hale \& R. W. Barker. 1977. Manure as a substrate for protein production via Hermetia illucens larvae. Proceedings of Cornell Agricultural Waste Management Conf. 93p.

Butler, T. A; L. J. Sikora; P. Steinhilber \& L. W. Douglass. 2001. Compost Age and Sample Storage Effects on Maturity Indicators of Biosolids Compost. Journal of Environmental Quality 30: 2141-2148.

Calvert, C. C.; N. O. Morgan \& R. D. Martin. 1970. House fly larvae: Biodegradation of hen excreta to usefull products. Poultry Science 49: 588-589.

Chakrabarti, S.; D. J. King; C. Afonso; D. Swayne; C. J. Cardona; D. R. Kuney \& A. C. Gerry. 2007. Detection and isolation of exotic Newcastle disease virus from field-collected flies. Journal of medical entomology 44: 840-844.

Chio, Y. \& W. J. Chen. 1982. Production of the maggot protein reared with swine manure. National Science Council 10: 677-682.

Cruz-Vásquez, C.; R. S. Martínez; M. I. Vitela; P. M. Ramos; M. M. T. Quintero \& V. Z. García. 2000. Variación anual de la infectación por Stomoxys calcintans (L.) (Diptera:Muscidae) en tres establos lecheros de Aguascalientes; México. Técnica Pecuaria en México 38: 135-142.

Haimi, J. 2000. Decomposer animals and bioremediation of soils. Environmental Pollution 107: 233-238.

Holdridge, L. R. 1967. Life zone ecology. San José, Tropical Science Center, $149 \mathrm{p}$.

Jacobs, R. D. 1998. Basic concepts for composting Poultry Mortalities. Dairy and Poultry Sciences Department. Florida Cooperative Extension Service. Institute of Food and Agricultural Science. FACT SHEET PS 43, 3 p.

Knapp, F. W.; A. E. Charron, \& J. G. Burg. 1992. Diseases transmission by the stable fly, p. 25-38. In: G. D. Thomas \& S. R. Skoda (Eds.). The stable fly: A pest of humans and domestic animals. Lincoln: University of Nebraska, $148 \mathrm{p}$.

Kostov, O.; Y. Tzvetkov; G. Petkova \& J. M. Lynch. 1996. Aerobic composting of plant wasted and effect on the yield of Ryegrass and tomatoes. Biology Fertility Soils 23: 20-25.
Labud, V. A.; L. G. Semenas \& F. Laos. 2003. Diptera of sanitary importance associated with composting of biosolids in Argentina. Revista de Saúde Pública 37: 722-728.

Laos, F.; L. Semenas \& V. Labud. 2004. Factors related to the attraction of flies at a biosolids composting facility (Bariloche; Argentina). The Science of the Total Environment 328: 33-40.

Lardé, G. 1989. Investigation on some factors affecting larval growth in a coffee-pulp bed. Biological Wastes 30: 11-19.

Lardé, G. 1990. Growth of Ornidia obesa (Diptera: Syrphidae) Larvae on decomposing coffee pulp. Biological Wastes 34: 73-76.

Lee, B-K.; M. J. Ellenbecker \& R. Moure-Ersaso. 2004. Alternatives for treatment and disposal cost reduction of regulated medical wastes. Waste Management 24: 143-151.

Martinez, E; P. Duque \& M. Wolff. 2007. Succession pattern of carrionfeeding insects in paramo; Colombia. Forensic Science International 166: $182-189$.

McAlpine, J. F.; B. V. Peterson; G. E. Shewell; H. J. Teskey; J. R. Vockeroth \& D. M. Wood. 1993. Manual of Nearctic Diptera. Monograph/ Agriculture Canada 27-28, Ottawa, Minister of Supply and Services, $1332 \mathrm{p}$.

Mckinley, V. L. \& J. R. Vestal. 1985. Physical and chemical correlates of microbial activity and biomass in composting municipal sewage sludge. Applied and Environmental Microbiology 50: 1395-1403.

Miller, R. W. 1992. The stable fly as a pest of dairy cattle, p. 12-20. In: G. D. Thomas \& S. R. Skoda (Eds.), The stable fly: A pest of humans and domestic animals (). Lincoln: University of Nebraska. 148 p.

Montoya,A. L.; J. D. Sanchez \& M. Wolff. 2009. Sinantropia de Calliphoridae (Diptera) de municipio La Pintada Antioquia-Colombia. Revista Colombiana de Entomología 35: 73-82.

Mramba, F; A. B. Broce \& L. Zurek. 2007. Vector competence of stable flies; Stomoxys calcitrans L. (Diptera: Muscidae); for Enterobacter sakazakii. Journal of Vector Ecology 32: 134-139.

Newton, G. L.; D. C. Sheppard \& S. A. Thompson. 1992. Use of the soldier fly to control houses; reduce manure volume and recycle nutrients in layer and swine facilities. Proceedings of Nutrition Conference, Atlanta, 17-19.

Newton, G. L.; D. C. Sheppard; S. A. Thompson \& S. I. Savage. 1995. Soldier fly benefits: House fly control; Manure Volume Reduction and Manure Nutrient Recycling. Anual Report, 1-9.

Pascual, J. A.; C. García; T. Hernández \& M. Ayuso. 1997. Changes in the microbial activity of an arid soil amended with urban organic wastes. Biology and Fertility of Soils 24: 429-434.

Perez-Eid, C \& N. Mouffok. 1999. Human urinary myiasis caused by Fannia canicularis (Diptera; Muscidae) larvae in Algeria. Presse médicale 28: 580-581.

Peterson, A. 1960. Larvae of Insects: An Introduction to Nearctic Species. 4th Edition. Columbus. 416 p.

Ramírez, J. J. 2000. Fitoplancton de agua dulce: aspectos ecológicos, taxonómicos y sanitarios. Medellín, Editorial Universidad de Antioquia, $205 \mathrm{p}$.

Sharholy, M.; K. Ahmad; G. Mahmood \& R. C. Trivedi. 2008. Municipal solid waste management in Indian cities - A review. Waste Management 28: $459-467$.

Sabrosky, C. W. 1987. Milichiidae, p. 903-908. In: J. F. McAlpine; B. V. Perterson; G. E. Shewell; H. J. Teskey; J. R. Vockeroth \& D. M. Wood (Eds.) Manual of Nearctic Diptera. Research Branch Agriculture Canada. Monograph $\mathrm{N}^{\circ} 28$. vi $+675-1332$.

Sharanowski, B. J.; E. G. Walker \& G. S. Anderson. 2008. Insect succession and decomposition patterns on shaded and sunlit carrion in Saskatchewan in three different seasons. Forensic Science International 179: 219240.

Sheppard, D. C. 1983. House fly and lesser fly control utilizing the black soldier fly in manure management systems for caged laying hens. Environmental Entomology 12: 1439-1442.

Smith, D. C.; J. C. Hughes. 2004. Changes in maturity indicators during the degradation of organic wastes subjected to simple composting procedures. Biology and Fertility of Soils 39: 280-286.

Sterh, F. 1987. Immature Insects. Volume I and II. Kendall/Hunt Publishing, 754 p. (I); 975 p. (II).

Stoffella, P. J. \& B. A. Kahn. 2001. Compost Utilization in Horticultural Cropping Systems. CRC Press LLC; $432 \mathrm{p}$.

Strom, P. F. 1985a. Effect of temperature on bacterial species diversity in 
thermophilic solid-waste composting. Applied and Environmental Microbiology 50: 899-905.

Strom, P. F. 1985b. Identification of thermophilic bacteria in solid-waste composting. Applied and Environmental Microbiology 50: 907-913.

Taylor, L. R. 1984. Assessing and interpreting the spatial distributions of insect populations. Annual Review of Entomology 29: 321-357.

T. M. E. C. C. 2001. Test Methods for the Examination of Composting and Compost. The United States Department of Agriculture and the United States.

Trautmann, N. \& E. Olynciw. 2000. Compost Microorganisms. Cornell Composting University. Available from: http://www.cfe.cornell.edu/ compost/microorg.html. (accessed 15 April 2007)

Tuomela, M.; M. Vikman; A. Hatakka \& M. Itävaara. 2000. Biodegradation of lignin in a compost environment: a review. Bioresource Technology 72: 169-183.

Wang, J.; Z. Li; Y. Chen; Q. Chen \& X. Yin. 2008. The succession and development of insects on pig carcasses and their significances in estimating PMI in south China. Forensic Science International 179: 11-18.

Wheeler, M. R. 1987. Drosophilidae, p. 1011-1018. In: J. F. McAlpine; B. V. Perterson; G. E. Shewell; H. J. Teskey; J. R. Vockeroth \& D. M. Wood (Eds.) Manual of Nearctic Diptera. Research Branch Agriculture Canada. Monograph $\mathrm{N}^{\circ} 28$. vi + 675-1332.

Williams, M. 2005. Using the black soldier fly; Hermetia illucens; as a value-added tool for the management of swine manure. The animal and poultry waste management center; North Carolina State University, $17 \mathrm{p}$.

Yang, Zeng-ru; Dong-wu. Bao \& Xiao-yan. Liang. 2005. Gastric myiasis caused by the larvae of Fannia canicularis. Chinese Journal of Parasitology \& Parasitic Diseases 23: 216.

Zbytniewski, R \& B. Buszewski. 2005. Characterization of natural organic matter (NOM) derived from sewage sludge compost. Part 1: chemical and spectroscopic properties Bioresource Technology 96: 471-478. 